\title{
The Role of lodine and Selenium in Autoimmune Thyroiditis
}

\author{
Author \\ L. H. Duntas \\ Affiliation \\ Evgenidion Hospital, Thyroid Unit, University of Athens, Athens, Greece
}

Key words
iodine
selenium
autoimmune thyroiditis
TREG cells

received 24.03 .2015

accepted 09.07.2015

Bibliography

DOI http://dx.doi.org/

10.1055/s-0035-1559631

Horm Metab Res 2015;

47: 721-726

(c) Georg Thieme Verlag KG Stuttgart · New York

ISSN 0018-5043

Correspondence

Prof. L. H. Duntas, MD

Evgenidion Hospital

Thyroid Unit

University of Athens

Papadiamantopoulou 20

Athens 11520

Greece

Tel.: + 30/210/6748 878

Fax: $+30 / 210 / 6756718$

ledunt@otenet.gr

\section{Abstract \\ $\nabla$}

Iodine and selenium (Se) are both essential elements to thyroid hormone economy, while they represent key players in the development of autoimmune thyroiditis.

Chronic high iodine intake has been associated in various studies with increased frequency of autoimmune thyroiditis. In susceptible individuals, iodine excess increases intra-thyroid infiltrating Th17 cells and inhibits T regulatory (TREG) cells development, while it triggers an abnormal expression of tumor necrosis factor-related apoptosis-inducing ligand (TRAIL) in thyrocytes, thus inducing apoptosis and parenchymal destruction. As was shown in a mouse model, high iodine supply leads to changes in the immunogenicity of the thyroglobulin molecule, upregulation of vascular intercellular adhesion molecule-1 (ICAM-1), and reactive oxygen species (ROS) generation in the thyrocytes. Serum Se levels were found decreased

\section{Introduction}

\section{$\nabla$}

Autoimmune thyroiditis (AIT), including Hashimoto Thyroiditis (HT) which is the most common form, is an organ-specific disorder characterized by a profound interaction between genetic and environmental factors [1,2]. The incidence of AIT is on the rise in many parts of the world. It exhibits a prevalence of about $12 \%$ depending on age (more frequent in postmenopausal women), gender (10 times more frequent in women) and race, being more common in Caucasians than in Blacks [3].

For a wide-ranging and analytic presentation of the environmental factors and their interaction with genetics, the reader is referred to several recent overviews [4-9]. This review discusses the pivotal role that both iodine and selenium may play in the development of AIT, while the main in Hashimoto thyroiditis and especially in Graves' disease as well as in thyroid-associated ophthalmopathy patients, the levels being related to the pathogenesis and outcome. Selenium is strongly involved, via the variable selenoproteins, in antioxidant, redox, and anti-inflammatory processes. Selenium enhances CD4+/CD25 FOXP3 and T regulatory cells activity while suppressing cytokine secretion, thus preventing apoptosis of the follicular cells and providing protection from thyroiditis. Selenium supplementation may be useful in autoimmune thyroid diseases, though, while usually well-tolerated, it should not be universally recommended, and it is also likely to be helpful for those with low Se status and autoimmunity. Broadly speaking, the achievement and maintenance of "selenostasis" as well as adequate urinary iodine excretion are mandatory to control disease, while, putatively, they may additionally be critical to preventing disease.

focus will be an update of the molecular mechanisms involved in the complex pathogenetic interactions of AIT.

\section{lodine \\ $\nabla$}

Environmental iodine deficiency, long a cause of iodine deficiency disorders round the world, has been substantially reduced thanks to the implementation of programs of mandatory food iodine fortification in numerous countries. However, while this endeavor has led to the virtual eradication in these regions of severe iodine deficiency, it has in parallel resulted in an increase in the prevalence of AIT. Meanwhile, it has recently been noted in various parts of the world that a decrease in iodine intake results in a lowering of the incidence of AIT [10]. 
The effect of a cautious iodization program aiming to adjust iodine intake to a low recommended level was evaluated in 2 identical cross-sectional population studies before and 4-5 years after mandatory iodine fortification of salt implemented in Denmark [11]. An increase in the prevalence of both thyroid peroxidase antibody (TPOAB) and thyroglobulin antibody (TgAB) was observed $4-5$ years after initiation of the program mostly in young women and at low concentrations of antibodies [11].

Excessive iodine intake for a period of 5 years in a populationbased study with 1085 participants in Sao Paulo resulted in excessive median urinary iodine excretion (MUIE) above $300 \mu \mathrm{g} / \mathrm{l}$ and $400 \mu \mathrm{g} / \mathrm{l}$, in 45.6 and $14.1 \%$, of the participants, respectively [12]. Additionally, an increase in the prevalence of AIT to $17 \%$ has been reported, $8 \%$ of the individuals being detected with hypothyroidism, while incidence of hyperthyroidism amounted to $3.3 \%$ of the study population.

More crucially, excessive iodine intake (MUIE $>300 \mu \mathrm{g} / \mathrm{l}$ ) could well become a serious public health concern because of its ability to substantially increase subclinical hypothyroidism and AIT rates [13]. This was recently documented in 2 Chinese communities manifesting both high $(261 \mu \mathrm{g} / \mathrm{l})$ and normal $(145 \mu \mathrm{g} / \mathrm{l})$ iodine intake levels [14], as well as in the Pescopagano survey in Italy. In the latter study conducted in a southern Italian village, 1411 people were examined in 1955 and 1148 in 2010 following the introduction of the salt iodization program [15]. The prevalence of hypothyroidism was found to be higher in $2010 \mathrm{vs.}$ 1995 (5.0 vs. $2.8 \%, \mathrm{p}<0.005$ ), chiefly due to an increased rate of subclinical hypothyroidism ( $\mathrm{SCH}$ ) in subjects younger than 15 years old. In parallel, TPOAB levels (19.5 vs. $12.6 \%$; $<0.0001$ ) and $\mathrm{HT}$ rates ( 14.5 vs. $3.5 \%$; $\mathrm{p}<0.0001$ ) were higher in 2010 than in 1995 [15].

It is therefore evident that even small differences in iodine intake can result in quite large differences in prevalence of thyroid diseases, given that iodine intakes both slightly below and above the recommended levels have been shown to be associated with an increase in disease risk [16]. Based on the above data, the best approach would be adherence to a narrow iodine intake interval so that a given population may achieve prevention of IDD and minimalization of the risk of autoimmune thyroid disease.

In various animal models, such as the BioBreeding/Worcester $(\mathrm{BB} / \mathrm{W})$ rat [17] and especially the nonobese diabetic (NOD) mouse [18], an autoimmune thyroiditis-prone animal model, the administration of iodine significantly enhanced and accelerated, in a dose-dependent manner, the incidence of AIT and thus corroborated the results that excess iodine is associated with thyroid autoimmunity.

\section{lodine and Autoimmune Thyroiditis: Mechanisms of Induction}

$\nabla$

The importance of Tg, which was the first thyroid-specific susceptibility gene to be identified, challenged by iodine in the induction of AIT has been well known since 1956 [19]. In 1992 it was demonstrated that a high iodine diet in the $\mathrm{BB} / \mathrm{W}$ rat, which results in spontaneous development of type 1 diabetes mellitus and lymphocytic thyroiditis, increases significantly the incidence of thyroiditis, while a low iodine diet has the opposite effect [20]. The authors also observed that the extent of Tg iodination is responsible for inducing lymphocytic thyroiditis in rat. Since then, it has been established that iodine triggers autoim- munity by inducing the generation of "cryptic peptides" within the Tg molecule, which in turn encompass "cryptic epitopes" on $\mathrm{Tg}$ with immunostimulatory properties [21]. In this line of evidence, it was demonstrated that $\mathrm{TgABs}$ are directed to the epitope B of Tg more frequently in iodized salt consumers than in nonconsumers [22]. Moreover, while autoreactive T cells may proliferate in response to normal $\mathrm{Tg}$, no reaction was seen in non-iodinated $\operatorname{Tg}[23,24]$. Iodine excess upregulates the expression of vascular intercellular adhesion molecule-1 (ICAM-1) on the surface of cell types including thyrocytes [25]. During the process of iodine organification in the thyroid, the generated reactive oxygen species (ROS), and especially hydrogen peroxide $\left(\mathrm{H}_{2} \mathrm{O}_{2}\right)$, can influence ICAM-1 expression and activate its transcription synergistically with iodine via the MAPK pathway $[26,27]$.

In $\mathrm{HT}$, an immunologic reaction is triggered in thyrocytes induced by the production of inflammatory cytokines, particularly interferon- $\gamma$ (IFN- $\gamma$ ), from $T$ helper (Th)1 type lymphocytes [28]. It has thus been hypothesized that IFN- $\gamma$ induces MHC class II expression on hemopoietic and epithelial cells and activates macrophages and ICAM-1, leading to leukocyte recruitment to the site of inflammation [29]. This postulated promotion of autoimmune disease activity by IFN- $\gamma$ is, however, till now controversial, since it was shown that IFN- $\gamma$ may possess diseasesuppressing activities [30]. NOD.H-2h4 transgenic mice, which had serum IFN- $\gamma$ levels similar to wild-type mice, showed upregulation of MHC class II on thyrocytes but failed to develop spontaneous thyroiditis. Immunization with murine thyroglobulin resulted in milder disease and decreased frequency of activated CD4+ lymphocytes in the cervical lymph nodes [31]. The latter suppressive effect was confirmed, as blockade of systemic IFN- $\gamma$ enhanced disease activity suggesting a local disease-limiting role of IFN- $\gamma$ in autoimmune thyroiditis. Potential mechanisms for this activity might be a decrease of the amount of thyroid antigens available for uptake by thyroid-resident antigen presenting cells (APCs), as well as the induction of regulatory proteins, which are members of the suppressor of the cytokine signaling (SOCS) family, particularly SOCS-1, that alleviate or terminate immunostimulatory signals [32].

On the other hand, IFN- $\gamma$ induces protein 10 (IP-10), which was identified as a chemokine exerting its function through binding to chemokine (C-X-C motif) receptor 3 (CXCR3) [33]. IP-10 and its receptor, CXCR3, appear to contribute to the pathogenesis of various organ-specific autoimmune diseases such as HT and Graves' disease (GD). It has been suggested that IP-10 levels might be a marker of the severity of the autoimmune process, as they were reported significantly higher in patients with a hypoechoic ultrasonographic pattern, which is a sign of a more severe lymphomonocytic infiltration in patients with thyroiditis [33]. These results are supported by an experimental study showing that high iodine intake in rats was associated with increased CD4(+) T cells and serum IP-10, indicating that high iodine consumption aggravates the inflammatory reaction in the thyroid by increasing serum IP-10 levels after induction of AIT with bovine thyroglobulin [34].

Other studies in NOD.H-2h4 mice have revealed a major role of Th17 cells in iodine-excess-induced AIT, given that they are capable of promoting an inflammatory reaction, which is negatively regulated by Th1, T helper type 2 (Th2), and regulatory $T$ (TREG) cells $[35,36]$. Thus, high iodine intake facilitates the production of Th17 cells from $\mathrm{T}$ cells and inhibits the development 


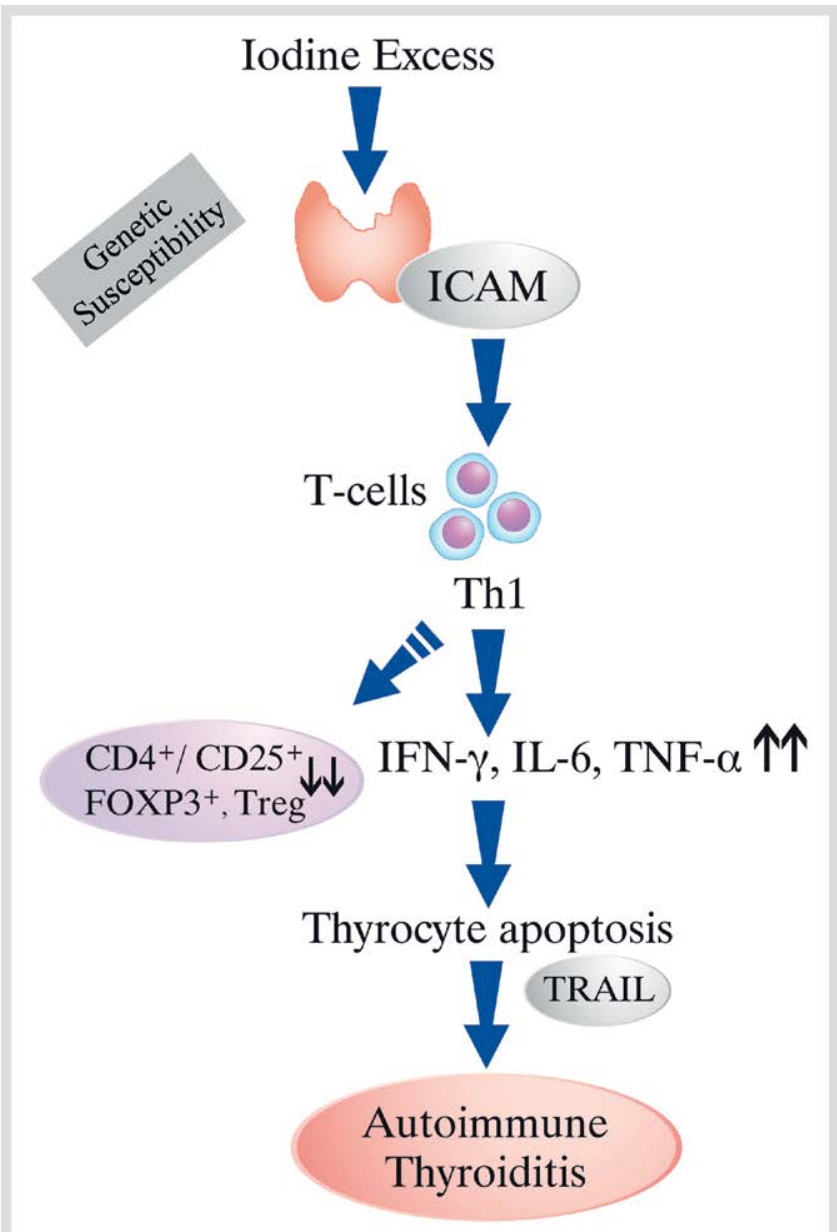

Fig. 1 High iodine intake may in susceptible individuals lead to an increased expression of ICAM-1 on thyroidal follicle cells, induce T helper cells to differentiate towards Thelper 1 (Th1), decrease CD4+/CD +25 , FOXP3 and TREG, increase cytokine secretion, induce apoptosis via abnormal TRAIL expression and mediate thyroid destruction. ICAM: Intracellular adhesion molecule; TRAIL: Tumor necrosis factor (TNF) related apoptosisinducing ligand (TRAIL); FOXP3: Forkhead/winged helix transcription factor p3 (FOXP3). (Color figure available online only).

of TREG cells. Interestingly, the increased concentration of serum IL-17 was inversely correlated with patients' residual thyroid function, while the expressed intra-thyroid IL-17 was correlated with the degree of local fibrosis [36]. The increased Th17:Th10 ratio that was found in HT patients after stimulation with thyroid specific self-antigens, together with an elevated baseline production of interleukin-6 (IL-6), of tumor growth factor- $\beta 1$ (TGF- $\beta 1$ ) and of mRNA encoding forkhead/winged helix transcription factor p3 missing exon 2 (FOXP3 $\Delta 2$ ), may contribute to the skewing towards Th17-cell responses in HT [36]. Furthermore, the expression of signal transducer and activator of transcription 3 (STAT3) was much higher, while the expression of forkhead/winged helix transcription factor p3 (FOXP3) was seen to be significantly lower and the proportion of Th17 cells much larger [37] ( $\bullet$ Fig. 1). Here, emphasis should be placed on the key role of the FOXP3 gene in the development of TREG cells, in view of the fact that mutations in the FOXP3 gene cause severe systemic autoimmune diseases in humans and in mice, while polymorphisms of the FOXP3 gene may alter FOXP3 function and/or expression and drive the genetic susceptibility to AITD [37].
Elevated iodine supplementation $(315 \mu \mathrm{g}$ and $615 \mu \mathrm{g}$ daily, respectively) in transgenic antibody-devoid mice, TAZ10, which are immunologically prone to AIT, alters the immune cell profile $\left[\mathrm{CD}^{+}\right.$and TREG cells, natural killer (NK) cells] and cytokine production, without affecting disease progression [38]. In contrast, enhanced iodide intake in NOD.H2(h4) mice accelerates the incidence and severity of spontaneous autoimmune thyroiditis, most probably via apoptosis of thyrocytes by CD4 and CD8 T cells and subsequently disruption of the immunoregulatory mechanisms [39]. A number of apoptosis signaling pathways, including Fas ligand and tumor necrosis factor (TNF)-related apoptosis-inducing ligand (TRAIL), are thought to be implicated in destructive thyroiditis. It is thus probable that excessive iodine induces TRAIL abnormal expression in the thyroid, promotes follicular cells apoptosis, and mediates thyroid destruction [40].

\section{Selenium and Autoimmune Thyroiditis}

In organisms, selenium either exists as low-molecular weight compounds, such as selenite, selenomethionine, methylselenol or selenomethylselenocysteine, or is assimilated as selenocysteine (amino acid; Sec) into selenium-containing proteins (selenoproteins). The thyroid contains more Se g/tissue than any other organ. Selenium is essential for the deiodination process of thyroxine by deiodinases (DIOs), and for the degradation of excessive generation of $\mathrm{H}_{2} \mathrm{O}_{2}$, via glutathione peroxidases (GPXs) and thioredoxin reductase (TRX) [41,42]. Therefore, many studies have been conducted in AIT patients in several countries with variable Se content in the soil with the aim of examining the effects of Se administration on the AIT markers [43]. Most of the studies, which applied organic selenium in the form of selenomethionine, showed a decrease of the TPOAB, while several other studies, using the inorganic form selenite, did not document any effect on the thyroid antibodies as compared to placebo. Two meta-analyses have confirmed a positive effect of Se on TPOAB and improvement of mood in HT [44,45], while another meta-analysis in the Cochrane library concluded that the evidence to support or refute the efficacy of selenium supplementation in patients with HT is incomplete [46]. In a very recent double-blind, randomized, placebo-controlled study including 230 women with singleton pregnancies, it was shown that low-dose Se $(60 \mu \mathrm{g} /$ day $)$ supplementation did not affect TPOAB but tended to change thyroid function, by decreasing TSH and FT4, in thyroid antibody positive patients [47]. The divergent results of the various studies may be due to the inhomogeneity of the groups of patients as well as to the variability of the basal Se and iodine state, the duration of the study time and the Se compounds applied [48].

Serum Se levels have been reported slightly lower in patients with AIT than in controls in a study performed in lower Austria [49]. Also, in another study designed in Denmark, patients with newly diagnosed AIT, especially GD, had significantly lower serum Se concentrations compared with random controls, indicating a potential link between inadequate selenium supply and overt autoimmune thyroid disease, especially GD [50].

In the same line of evidence, serum Se levels were found low, as compared to controls, in HT and especially in GD patients, while high Se levels $(>120 \mu \mathrm{g} / \mathrm{l})$ were associated with remission and better outcome [51]. Moreover, serum Se levels were lower in patients with thyroid associated orbitopathy (TAO) as compared 
with GD in an Australian study population with marginal selenium status [52]. These findings underscore the association of Se deficiency and thyroid autoimmunity and strongly indicate that low Se levels may reflect an increased risk factor for TAO in patients with Graves' disease. Se supplementation in GD patients with mild TAO statistically significantly improved ocular involvement and Quality of Life, while it slowed disease progression following 3 and 6 months treatment [53].

These results thus point to the possibility that patients might benefit from an improvement in their Se status, both as a means of reducing the individual autoimmunity risk as well as to remedy a Se deficiency, which often develops during the course of illness.

\section{Mechanisms of Selenium Action}

$\checkmark$

Selenium has variably been linked to thyroid autoimmunity. Besides the regulatory role that Se possesses in the deiodination of thyroid hormones, being a central constitutional element of the DIOs, Se neutralizes, via GPX1 and GPX3, the diffusion and activity of overproduced $\mathrm{H}_{2} \mathrm{O}_{2}$ and thus, it conserves the integrity of the thyrocytes [54,55]. Accordingly, it was shown that by means of a conditional gene knockout strategy, ablation of Sec tRNA[Ser]Sec results in the loss of expression of the whole selenoprotein set, or selenoproteome, in both hepatocytes and $\mathrm{T}$ cells [56].

CD4+ T cells can differentiate into either Th1 or Th2 cells, based on the activation of a pro-Th1 or a pro-Th2 environment [57]. High dietary Se may trigger an oxidative burst in response to $\mathrm{T}$ cell receptor (TCR) stimulation [57]. It is known that Th0 and Th1 clones may function as helper T cells, leading to production of autoantibodies against Tg and TPO [58]. TCR induces differentiation of CD + T cells into FOXP3 + TREG cells, which might be influenced by high dietary Se levels [59]. The reduction or functional abnormality of CD25+CD4 + TREG cells leads to the development of autoimmune disease. It is notable that, as was demonstrated in human leucocyte antigen DR3 (DRB1 *0301) transgenic class II-knock-out nonobese diabetic mice, depletion of CD4+CD25+TREG cells prior to sodium iodide treatment induced destructive thyroiditis (68\%) and exacerbates serum anti-Tg antibodies [60]. In an experimental study, inorganic Se inhibited in a dose-dependent matter the expression of HDL-DR molecules by reducing the radical oxygen species (ROS) in cultures of human thyrocytes exposed to IFN- $\gamma$ [61]. Se supplementation in patients with AIT affects dose-dependently IL-2 and other cytokines variably involved in the pathogenesis of AIT [62] (॰ Fig. 2).

Selenium may indirectly inhibit TNF activation and cytokine release. It is noteworthy, that by increasing Se supplementation, receptor activator for nuclear factor-KB ligand (RANKL) that is related to TNF- $\alpha$ activation may be reduced [57]. In this line of evidence, in an experimental study investigating the effects of SeMet on proinflammatory cytokines release from monocyte and lymphocytes of patients with untreated HT, a significant inhibition of IFN- $\gamma$ and IL-2 by SeMet was demonstrated, an effect that was potentiated when combined treatment with LT4 and SeMet was applied [63]. Thus, Se exhibits directly and indirectly anti-inflammatory and antioxidative actions, which have been variably revealed in studies on immune cells from humans and animals. In this connection, Se supplementation as selenite $(50 \mu \mathrm{g} /$ day or $100 \mu \mathrm{g} /$ day $)$ increased both GPX1 and GPX4 activ-

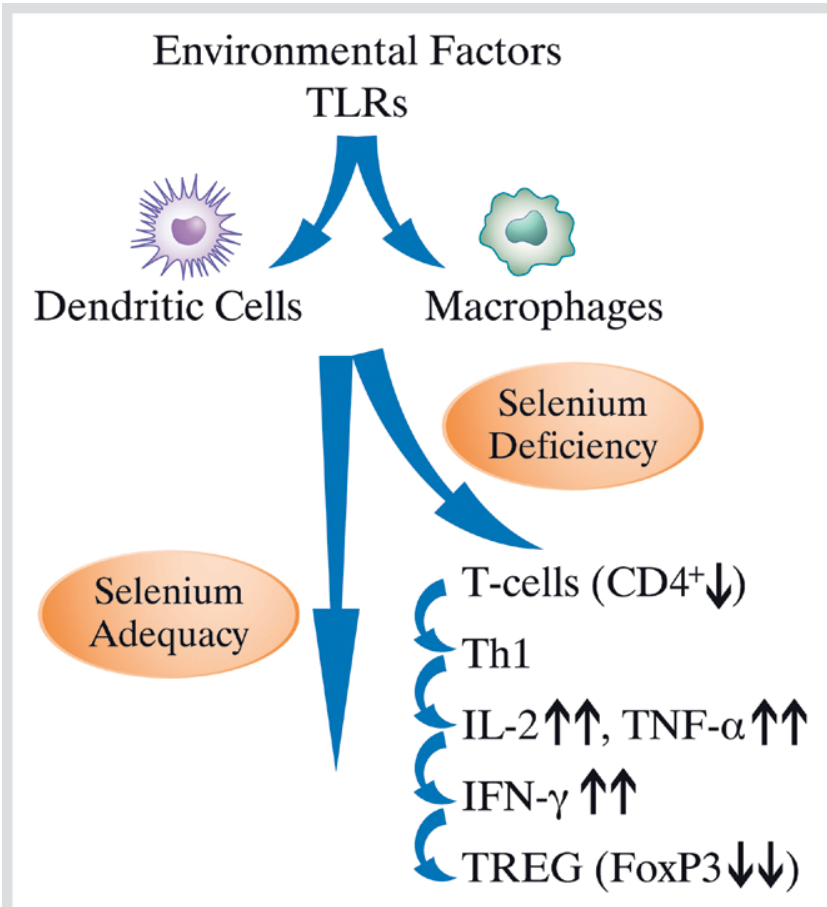

Fig. 2 Increased Se intake induces, via activation of the T cell receptor (TCR), differentiation of $C D 4+T$ cells into $C D 25+$ Foxp $3+T$ regulatory cells (TREG). Adequate levels of Se intake do not affect $\mathrm{T}$ cells and $\mathrm{T}$ helper cells (Th0) vs. Th1 or Th2 differentiation. In contrast, Se deficiency, as an environmental factor, increases T-cell activation, while the Thelper-1 (Th1)/T helper-2 (Th2) ratio may shift to a Th1-type response, increasing such cytokines as IL-2, TNF- $\alpha$, IFN- $\gamma$, thereby reducing CD25 + T regulatory cells (TREG) + Foxp3 and in parallel inhibiting an activation of dendritic cells and macrophages by Toll-like receptor (TLR) cells [57,61]. TREG likely responds to different ligands for TLRs, thus the TLRs may exert different effects on TREG, depending on the degree of inflammation, resulting in more suppression or, in contrast, abrogation of suppression [68].

(Color figure available online only).

ity in lymphocytes from supplemented individuals compared to controls [63].

Macrophages, a class of myeloid leukocytes with phagocytic activity, detect the presence of signature molecules associated with microbial infection and tissue damage signaling properties [64]. An experimental study recently demonstrated that the enhanced release of $\mathrm{H}_{2} \mathrm{O}_{2}$ by macrophages after zymosan stimulation could be directly attributable to loss of glutathione peroxidase (GSH-Px) activity, thus leading to reduced peroxide breakdown [65]. Moreover, the influence of a selenium-deficient diet in mice and rats has been studied via investigation into the GSH-Px and secretory activities of peritoneal macrophages, mitogenesis of spleen cells, and adjuvant arthritis. Macrophage GSH-Px activity was significantly reduced by 9 weeks on the selenium-deficient diet. Interestingly, this reduction was associated with enhanced macrophage $\mathrm{H}_{2} \mathrm{O}_{2}$ release following zymosan stimulation after 12 weeks on the diet, this accompanied by a similar trend in chemiluminescence and reduced mitogenesis of spleen cell cultures to $\mathrm{T}$ and $\mathrm{B}$ cell mitogens after 8 weeks on the diet [65].

Mouse macrophages treated with lipopolysaccharide (LPS) demonstrated an increase in TXRND1 expression, while the mRNA or protein expression of other selenoproteins, including GPX enzymes, was less affected, suggesting a significant role of TXNRD1 in the regulation of redox status in macrophages [66]. 
The incorporation of radiolabeled selenium into protein during LPS stimulation revealed TRXND1 as the only LPS-inducible selenoprotein in macrophages. In mice, macrophage-specific ablation of TRXND1 results in a drastic decrease in the expression of VSIG4, a B7 family protein known to suppress $\mathrm{T}$ cell activation [66]. These results suggest a link between selenium metabolism and immune signaling and identify TRXND1 as both a regulator and a regulated target in the macrophage gene expression network [66].

A significant association between the SEPS1-105 GA and AA genotypes and HT was found in a study investigating the role of polymorphisms in the promoter region of selenoprotein S, and SEPS gene, in the risk for developing HT [67]. It is of interest that male patients with HT represent a 3.94 times increased risk for carrying the A allele than women. This was the first study showing polymorphisms of selenoproteins associated with the risk of HT. To conclude, this review underlines the significance of the 2 essential elements, iodine and Se, for thyroid function and the fact that both excess and deficiency are intimately related with thyroid autoimmunity. It is thus apparent that dietary intake should imply maintenance of normal iodine and Se levels while avoiding either increased or diminished serum and/or urine excretion levels.

\section{Conflict of Interest}

\section{$\nabla$}

The author declares no conflict of interest.

\section{References}

1 Hollowell JG, Staehling NW, Flanders WD, Hannon WH, Gunter EW, Spencer CA, Braverman LE. Serum TSH, T(4), and thyroid antibodies in the United States population (1988 to 1994): National Health and Nutrition Examination Survey (NHANES III). J Clin Endocrinol Metab 2002; 87: 489-499

2 Lind P, Langsteger W, Molnar M, Gallowitsch HJ, Mikosch P, Gomez I. Epidemiology of thyroid diseases in iodine sufficiency. Thyroid 1998; 8: 1179-1183

3 Bülow Pedersen I, Knudsen N, Jørgensen T, Perrild H, Ovesen L, Laurberg P. Large differences in incidences of overt hyper- and hypothyroidism associated with a small difference in iodine intake: a prospective comparative register-based population survey. J Clin Endocrinol Metab 2002; 87: 4462-4469

4 Duntas $\mathrm{LH}$. Environmental factors and autoimmune thyroiditis. Nat Clin Pract Endocrinol Metab 2008; 4: 454-460

5 Burek CL, Talor MV. Environmental triggers of autoimmune thyroiditis. J Autoimmun 2009; 33: 183-189

6 Rose NR. The genetics of autoimmune thyroiditis: the first decade. J Autoimmun 2011; 37: 88-94

7 Duntas $\mathrm{LH}$. Environmental factors and thyroid autoimmunity. Ann Endocrinol (Paris) 2011; 72: 108-113

8 Tanda ML, Piantanida E, Lai A, Lombardi V, Dalle Mule I, Liparulo L, Pariani N, Bartalena $L$. Thyroid autoimmunity and environment. Horm Metab Res 2009; 41: 436-442

9 Eschler DC, Hasham A, Tomer Y. Cutting edge: the etiology of autoimmune thyroid diseases. Clin Rev Allergy Immunol 2011; 41: 190-197

10 Miranda DM, Massom JN, Catarino RM, Santos RT, Toyoda SS, Marone MM, Tomimori EK, Monte O. Impact of nutritional iodine optimization on rates of thyroid hypoechogenicity and autoimmune thyroiditis: a cross-sectional, comparative study. Thyroid 2015; 25: 118-124

11 Pedersen IB, Knudsen N, Carlé A, Vejbjerg P, Jørgensen T, Perrild H, Ovesen $L$, Rasmussen $L B$, Laurberg $P$. A cautious iodization programme bringing iodine intake to a low recommended level is associated with an increase in the prevalence of thyroid autoantibodies in the population. Clin Endocrinol (Oxf) 2011; 75: 120-126

12 Camargo RY, Tomimori EK, Neves SC, GS Rubio I, Galrão AL, Knobel M, Medeiros-Neto G. Thyroid and the environment: exposure to excessive nutritional iodine increases the prevalence of thyroid disorders in Sao Paulo, Brazil. Eur J Endocrinol 2008; 159: 293-299
13 Vanderpump $M$. Thyroid autoimmunity following an iodization programme. Clin Endocrinol (Oxf) 201 75: 10-11

14 Teng X, Shan Z, Chen Y, Lai Y, Yu J, Shan L, Bai X, Li Y, Li N, Li Z, Wang $S$, Xing $Q$ Xue H, Zhu L, Hou X, Fan C, Teng W. More than adequate iodine intake may increase subclinical hypothyroidism and autoimmune thyroiditis: a cross-sectional study based on two Chinese communities with different iodine intake levels. Eur J Endocrinol 2011; 164: 943-950

15 Aghini Lombardi F, Fiore E, Tonacchera M, Antonangeli L, Rago T, Frigeri $M$, Provenzale AM, Montanelli L, Grasso L, Pinchera A, Vitti P. The effect of voluntary iodine prophylaxis in a small rural community: the Pescopagano survey 15 years later. J Clin Endocrinol Metab 2013; 98: 1031-1039

16 Laurberg P, Cerqueira C, Ovesen L, Rasmussen LB, Perrild H, Andersen $S$, Pedersen IB, Carlé A. lodine intake as a determinant of thyroid disorders in populations. Best Pract Res Clin Endocrinol Metab 2010; 24: $13-27$

17 Allen EM, Appel MC, Braverman LE. The effect of iodide ingestion on the development of spontaneous lymphocytic thyroiditis in the diabetesprone BB/W rat. Endocrinology 1986; 118: 1977-1981

18 Rasooly L, Burek CL, Rose NR. Iodine-induced autoimmune thyroiditis in NOD-H-2h4 mice. Clin Immunol Immunopathol 1996; 81: 287-292

19 Rose NR, Witebsky E. Changes in the thyroid glands of rabbits following active immunization with rabbit thyroid extract. J Immunol 1956; 76: 417-427

20 Carayanniotis G. Molecular parameters linking thyroglobulin iodination with autoimmune thyroiditis. Hormones 2011; 10: 27-35

21 Latrofa F, Fiore E, Rago T, Antonangeli L, Montanelli L, Ricci D, Provenzale $M A$, Scutari $M$, Frigeri $M$, Tonacchera $M$, Vitti P. Iodine contributes to thyroid autoimmunity in humans by unmasking a cryptic epitope on thyroglobulin. J Clin Endocrinol Metab 2013; 98: E1768-E1774

22 Rose NR, Saboori AM, Rasooly L, Burek CL. The role of iodine in autoimmune thyroiditis. Crit Rev Immunol 1997; 17: 511-517

23 Kolypetri P, Noel NA, Carayanniotis KA, Carayanniotis G. Iodine content of thyroglobulin in Nod.H2h4 mice developing iodine-accelerated autoimmune thyroiditis. Hormones (Athens) 2010; 9: 151-160

24 Weetman AP, Cohen S, Makgoba MW, Borysiewicz LK. Expression of an intercellular adhesion molecule, ICAM-1, by human thyroid cells. J Endocrinol 1989; 122: 185-191

25 Burek CL, Rose NR. Autoimmune thyroiditis and ROS. Autoimmun Rev 2008; 7: 530-537

26 Colin IM, Poncin S, Levêque P, Gallez B, Gérard AC. Differential regulation of the production of reactive oxygen species in Th1 cytokinetreated thyroid cells. Thyroid 2014; 24: 441-452

27 Sharma RB, Alegria JD, Talor MV, Rose NR, Caturegli P, Burek CL. Iodine and IFN-gamma synergistically enhance intercellular adhesion molecule 1 expression on NOD.H2h4 mouse thyrocytes. J Immunol 2005; 174: 7740-7745

28 O'Shea JJ, Ma A, Lipsky P. Cytokines and autoimmunity. Nat Rev Immunol 2002; 2: 37-45

29 Barin JG, Afanasyeva M, Talor MV, Rose NR, Burek CL, Caturegli P. Thyroid-specific expression of IFN-limits experimental autoimmune thyroiditis by suppressing lymphocyte activation in cervical lymph nodes. J Immunol 2003; 170: 5523-5529

30 Gadina MD, Hilton JA, Johnston A, Morinobu A, Lighvani YJ, Zhou R, Visconti J, O'Shea J. Signaling by type I and II cytokine receptors: ten years after. Curr Opin Immunol 2001; 13: 363-373

31 Horie I, Abiru N, Nagayama Y, Kuriya G, Saitoh O, Ichikawa T, Iwakura $Y$, Eguchi $K$. T helper type 17 immune response plays an indispensable role for development of iodine-induced autoimmune thyroiditis in nonobese diabetic-H2h4 mice. Endocrinology 2009; 150: 5135-5142

32 Ruffilli I, Ferrari SM, Colaci M, Ferri C, Fallahi P, Antonelli A. IP-10 in autoimmune thyroiditis. Horm Metab Res 2014; 46: 597-602

33 Cui SL, Yu J, Shoujun L. Iodine Intake Increases IP-10 Expression in the Serum and Thyroids of Rats with Experimental Autoimmune Thyroiditis. Int J Endocrinol 2014; 2014: 581069

34 Li D, Cai W, Gu R, Zhang Y, Zhang H, Tang K, Xu P, Katirai F, Shi W, Wang $L$, Huang T, Huang $B$. Th17 cell plays a role in the pathogenesis of Hashimoto's thyroiditis in patients. Clin Immunol 2013; 149: 411-420

35 Yang X, Gao T, Shi R, Zhou X, Qu J, Xu J, Shan Z, Teng W. Effect of iodine excess on Th1, Th2, Th17, and Treg cell subpopulations in the thyroid of NOD.H-2h4 mice. Biol Trace Elem Res 2014; 159: 288-296

36 Kristensen B, Hegedüs L, Madsen HO, Smith TJ, Nielsen CH. Altered balance between self-reactive Th17 cells and Th10 cells and between fulllength FOXP3 and FOXP3 splice variants in Hashimoto's thyroiditis. Clin Exp Immunol 2015; 180: 58-69 
37 Ban Y, Tozaki T, Tobe T, Ban Y, Jacobson EM, Concepcion ES, Tomer Y. The regulatory $\mathrm{T}$ cell gene FOXP3 and genetic susceptibility to thyroid autoimmunity: an association analysis in Caucasian and Japanese cohorts. J Autoimmun 2007; 28: 201-207

38 Ehlers M, Thiel A, Papewalis C, Domröse A, Stenzel W, Bernecker C, Haase M, Allelein S, Schinner S, Willenberg HS, Feldkamp J, Schott M. Enhanced iodine supplementation alters the immune process in a transgenic mouse model for autoimmune thyroiditis. Thyroid 2014; 24: 888-896

39 Kolypetri P, Carayanniotis G. Apoptosis of NOD.H2 h4 thyrocytes by low concentrations of iodide is associated with impaired control of oxidative stress. Thyroid 2014; $24: 1170-1178$

$40 \mathrm{Yu}$ X, Li L, Li Q, Zang X, Liu Z. TRAIL and DR5 promote thyroid follicular cell apoptosis in iodine excess-induced experimental autoimmune thyroiditis in NOD mice. Biol Trace Elem Res 2011; 143: 1064-1076

41 Aaseth J, Frey H, Glattre E, Norheim G, Ringstad J, Thomassen Y. Selenium concentrations in the human thyroid gland. Biol Trace Elem Res 1990; 24: 147-152

42 Beckett GJ, Arthur JR. Selenium and endocrine systems. J Endocrinol 2005; 184: 455-465

43 Duntas LH. Selenium and the thyroid: a close-knit connection. J Clin Endocrinol Metab 2010; 95: 5180-5188

44 Toulis KA, Anastasilakis AD, Tzellos TG, Goulis DG, Kouvelas D. Selenium supplementation in the treatment of Hashimoto's thyroiditis: a systematic review and a meta-analysis. Thyroid 2010; 20: 1163-1173

45 Fan Y, Xu S, Zhang H, Cao W, Wang K, Chen G, Di H, Cao M, Liu C. Selenium supplementation for autoimmune thyroiditis: a systematic review and meta-analysis. Int J Endocrinol 2014; 2014: 904573

46 van Zuuren EJ, Albusta AY, Fedorowicz Z, Carter B, Pijl H. Selenium Supplementation for Hashimoto's Thyroiditis: Summary of a Cochrane Systematic Review. Eur Thyroid J 2014; 3: 25-31

47 Mao J, Pop VJ, Bath SC, Vader HL, Redman CW, Rayman MP. Effect of low-dose selenium on thyroid autoimmunity and thyroid function in UK pregnant women with mild-to-moderate iodine deficiency. Eur J Nutr 2014 [Epub ahead of print]

48 Duntas LH, Benvenga S. Selenium: an element for life. Endocrine 2015; 48: 756-775

49 Wimmer I, Hartmann T, Brustbauer R, Minear G, Dam K. Selenium levels in patients with autoimmune thyroiditis and controls in lower Austria. Horm Metab Res 2014; 46: 707-709

50 Bülow Pedersen I, Knudsen N, Carlé A, Schomburg L, Köhrle J, Jørgensen $T$, Rasmussen $L B$, Ovesen L, Laurberg P. Serum selenium is low in newly diagnosed Graves' disease: a population-based study. Clin Endocrinol (Oxf) 2013; 79: 584-590

51 Wertenbruch T, Willenberg HS, Sagert C, Nguyen TB, Bahlo M, Feldkamp J, Groeger C, Hermsen D, Scherbaum WA, Schott M. Serum selenium levels in patients with remission and relapse of graves' disease. Med Chem 2007; 3: 281-284

52 Khong JJ, Goldstein RF, Sanders KM, Schneider H, Pope J, Burdon KP, Craig JE, Ebeling PR. Serum selenium status in Graves' disease with and without orbitopathy: a case-control study. Clin Endocrinol (Oxf) 2014; 80: 905-910

53 Marcocci C, Kahaly GJ, Krassas GE, Bartalena L, Prummel M, Stahl M, Altea MA, Nardi M, Pitz S, Boboridis K, Sivelli P, von Arx G, Mourits MP, Baldeschi L, Bencivelli W, Wiersinga W. Selenium and the course of mild Graves' orbitopathy. European Group on Graves' Orbitopathy. N Engl J Med 2011; 364: 1920-1931
54 Hoffmann FW, Hashimoto AC, Shafer LA, Dow S, Berry MJ, Hoffmann PR. Dietary selenium modulates activation and differentiation of CD4+ $\mathrm{T}$ cells in mice through a mechanism involving cellular free thiols. J Nutr 2010; 140: 1155-1161

55 Hoffmann PR. Mechanisms by which selenium influences immune responses. Arch Immunol Ther Exp (Warsz) 2007; 55: 289-297

56 Carlson BA, Yoo MH, Sano Y, Sengupta A, Kim JY, Irons R, Gladyshev VN, Hatfield DL, Park JM. Selenoproteins regulate macrophage invasiveness and extracellular matrix related gene expression. BMC Immunol 2009; 10: 57

57 Huang $Z$, Rose AH, Hoffmann PR. The role of selenium in inflammation and immunity: from molecular mechanisms to therapeutic opportunities. Antioxid Redox Signal 2012; 16: 705-743

58 Fisfalen ME 1, Soltani K, Kaplan E, Palmer EM, van Seventer GA, Straus FH, Diaz M, Ober C, DeGroot LJ. Evaluating the role of Th0 and Th1 clones in autoimmune thyroid disease by use of Hu-SCID chimeras. Clin Immunol Immunopathol 1997; 85: 253-264

59 Takahashi $T$, Sakaguchi S. Naturally arising CD25+CD4+ regulatory T cells in maintaining immunologic self-tolerance and preventing autoimmune disease. Curr Mol Med 2003; 3: 693-706

60 Flynn JC, Meroueh C, Snower DP, David CS, Kong YM. Depletion of CD4 + CD25 + regulatory $T$ cells exacerbates sodium iodide-induced experimental autoimmune thyroiditis in human leucocyte antigen DR3 (DRB1 * 0301) transgenic class II-knock-out non-obese diabetic mice. Clin Exp Immunol 2007; 147: 547-554

61 Balázs C, Kaczur V. Effect of Selenium on HLA-DR expression of thyrocytes. Autoimmune Dis 2012; 74635

62 Tan L, Sang ZN, Shen J, Wu YT, Yao ZX, Zhang JX, Zhao N, Zhang WQ. Selenium supplementation alleviates autoimmune thyroiditis by regulating expression of TH1/TH2 cytokines. Biomed Environ Sci 2013; 26: 920-925

63 Krysiak R, Okopien $B$. The effect of levothyroxine and selenomethionine on lymphocyte and monocyte cytokine release in women with Hashimoto's thyroiditis. J Clin Endocrinol Metab 2011; 96: 2206-2215

64 Gordon S, Taylor PR. Monocyte and macrophage heterogeneity. Nat Rev Immunol 2005; 5: 953-964

65 Parnham MJ, Winkelmann J, Leyck S. Macrophage, lymphocyte and chronic inflammatory responses in selenium deficient rodents. Association with decreased glutathione peroxidase activity. Int J Immunopharmacol 1983; 5455-5461

66 Carlson BA, Yoo MH, Conrad M, Gladyshev VN, Hatfield DL, Park JM. Protein kinase-regulated expression and immune function of thioredoxin reductase 1 in mouse macrophages. Mol Immunol 2011; 49: 311-316

67 Santos LR, Durães C, Mendes A, Prazeres H, Alvelos MI, Moreira CS, Canedo P, Esteves C, Neves C, Carvalho D, Sobrinho-Simões M, Soares $P$. A polymorphism in the promoter region of the selenoprotein $S$ gene (SEPS1) contributes to Hashimoto's thyroiditis susceptibility. J Clin Endocrinol Metab 2014; 99: E719-E723

68 Sutmuller R, Garritsen A, Adema GJ. Regulatory T cells and toll-like receptors: regulating the regulators. Ann Rheum Dis 2007; 66 (Suppl 3): iii91-iii95 